Jurnal Ilmu Kesehatan Masyarakat. 202I; I0 (4): 230-237
Jurnal Ilmu Kesehatan Masyarakat
(The Public Health Science Journal)
Journal Homepage: http://journals.stikim.ac.id/index.php/jikm

\title{
Gambaran Konsumsi Gula, Garam, dan Lemak (Minyak) pada Anak Sekolah
}

\author{
Kristiawan Prasetyo Agung Nugroho', Gelora Mangalik², Tesalonika Gisela \\ Rembet $^{3}$ \\ ${ }^{1-3}$ Program Studi Gizi, Fakultas Kedokteran dan Ilmu Kesehatan, Universitas Kristen Satya Wacana \\ Jalan Kartini No. 11A Kota Salatiga, Jawa Tengah \\ Email : kristiawan.nugroho@uksw.edu' ${ }^{1}$,gelora.mangalik@uksw.edu²,472014028@student.uksw.edu ${ }^{3}$
}

\begin{abstract}
Abstrak
Anak usia sekolah (6-12 tahun) merupakan kelompok usia dengan tumbuh kembang pesat kedua setelah masa Balita. Perhatian orangtua dan keluarga penting dalam pemilihan makanan. Penelitian ini bertujuan untuk mengetahui gambaran konsumsi garam, gula, dan lemak (minyak) siswa di beberapa sekolah dasar di Kecamatan Tondano Utara, Kabupaten Minahasa. Jenis penelitian adalah deskriptif kuantitatif dengan teknik pengambilan data purposive sampling. Data dianalisa secara deskriptif dalam bentuk tabel dan grafik. Penelitian dilakukan pada bulan Mei 2020. Responden penelitian sebanyak 60 siswa kelas I-IV dari SD GMIM Wulauan, SD GMIM Tonsea Lama, dan SD Inpres Marawas. Pengambilan data menggunakan kuesioner untuk mengetahui faktor-faktor yang mempengaruhi perilaku makan responden, SQ-FFQ (data kebiasaan makan), Food Recall $2 \times 24$ jam (data asupan makan), serta pengukuran antropometri. Hasil Food Recall 2×24 jam didapatkan bahwa gambaran konsumsi asupan garam sebanyak $432,02 \mathrm{mg}$, asupan gula sebanyak 0,02 g, dan asupan minyak (lemak) 32,23 g, berada pada kategori kurang. Konsumsi Gula, Garam, dan Lemak (minyak) (GGL) responden termasuk kurang. Asupan GGL tetap perlu dijaga agar tidak melebihi batas konsumsinya dengan membatasi jajanan yang manis, gurih, dan berlemak serta memberikan pendidikan gizi kepada anak tentang makanan dan jajanan yang sehat.
\end{abstract}

Kata Kunci: Anak sekolah, garam, gula, lemak

\begin{abstract}
School-age children (6-I 2 years) are the second fastest-growing age group after toddlerhood. Parents and family's attention is important in food selection. This study aims to describe the consumption of salt, sugar, and fat (oil) of students in several elementary schools in North Tondano District, Minahasa Regency. This type of research is quantitative descriptive with purposive sampling data collection technique. Data were analyzed descriptively in tables and graphs. The research was conducted in May 2020. The research respondents were 60 grade I - IV students from SD GMIM Wulauan, SD GMIM Tonsea Lama, and SD Inpres Marawas. Collecting data using a questionnaire to determine the factors that influence the respondent's eating behavior, SQ-FFQ (eating habits data), Food Recall $2 \times 24$ hours (food intake data), and anthropometric measurements. The results of the $2 \times 24$ hour Food Recall show that the picture of salt intake as much as $432.02 \mathrm{mg}$, sugar intake of 0.02 grams, and oil (fat) intake of 32.23 grams, is in a low category. Consumption of sugar, salt, and fat (oil) (GGL) of respondents is considered insufficient. GGL intake still needs to be maintained so as not to exceed the consumption limit by limiting sweet, savory, and fatty snacks as well as providing nutritional education to children about healthy food and snacks.
\end{abstract}

Keywords : School-age children, intake of sugar, salt, fat 


\section{Pendahuluan}

Anak usia sekolah (6-12 tahun) merupakan kelompok usia dengan tumbuh kembang pesat kedua setelah masa Balita. Perhatian orang tua dan orang-orang terdekat sangat penting dalam pemilihan makanan. Asupan gizi yang yang baik dan benar sangat diperlukan agar anak dapat bertumbuh dan berkembang secara optimal. ${ }^{1}$

Jajanan anak sekolah masih memegang peran penting dalam pola konsumsi anak setiap harinya ketika masih berada di lingkungan sekolah. Kandungan beberapa zat gizi seperti karbohidrat dan lemak dari jajanan umumnya lebih dominan jika dibandingkan dengan zat gizi lainnya. Konsumsi energi, lemak dan garam yang tinggi bersama dengan rendahnya pengeluaran energi karena kurangnya aktifitas fisik dan gaya hidup sedenter, berpotensi menyebabkan kegemukan.

Kebiasaan makan yang terbentuk pada usia sekolah serta jenis makanan yang disukai atau tidak disukai merupakan dasar bagi pola konsumsi makanan dan asupan gizi anak pada usia selanjutnya. ${ }^{2}$ Pemilihan makan anak turut dipengaruhi oleh idola atau tokoh populer yang menarik bagi anak, kebiasaan makan teman sebaya, serta lingkungan tempat tinggal. ${ }^{3}$ Sebanyak $95 \%$ anak diberi uang saku oleh orang tuanya sehingga kemungkinan untuk membeli jajanan lebih tinggi. ${ }^{4}$

Permenkes RI No.30 tahun 2013 menganjurkan tentang takaran konsumsi gula untuk satu hari tidak lebih dari 50 gram, garam tidak lebih dari 5 gram dan lemak tidak lebih dari 67 gram, tetapi saat ini kerap ditemui jajanan yang mungkin melebihi batas dari takaran konsumsi harian tersebut. ${ }^{5}$ Hal tersebut terjadi untuk menarik pembeli melalui cita rasa yang manis atau gurih agar terasa lebih lezat, seperti minuman-minuman yang kekinian yakni bubble tea, chesse tea, dan sebagainya.

Makanan-makanan yang merupakan pencetus terjadinya obesitas atau kegemukan adalah jenis olahan fast food yang saat ini lebih diminati oleh berbagai kalangan usia, seperti burger, hot dog, ayam goreng tepung, dan pizza. Beberapa contoh makanan tersebut mengandung kadar garam dan lemak yang tinggi, tetapi rendah serat. BPOM RI menganjurkan untuk mengkonsumsi gula yang tidak lebih dari 4 sendok makan, garam tidak lebih dari 1 sendok teh, dan tidak lebih dari 5 sendok makan untuk konsumsi minyak/lemak. ${ }^{6}$

Makanan selingan (snack) yang dikonsumsi secara berlebihan dan tidak mengenal waktu dapat mengakibatkan obesitas. $^{7}$ Selain obesitas, kelebihan konsumsi gula, garam, dan lemak di dalam tubuh dapat menyebabkan berbagai kondisi yang merugikan yakni dapat memicu terjadinya penyakit tidak menular (PTM). Anak yang mengkonsumsi garam berlebih akan menyebabkan peningkatan berat badan dan berpotensi meningkatkan tekanan darah secara dramatis. Anak yang mengkonsumsi $1.000 \mathrm{mg}$ garam setiap harinya berisiko mengalami tekanan darah tinggi dan dapat meningkat sampai $74 \%$ pada anak dengan kelebihan berat badan atau obesitas, sedangkan pada anak yang berbadan normal hanya naik sampai $6 \%$. Data tersebut didasarkan pada kajian yang melibatkan 6.200 anak-anak dan remaja yang berusia 8-18 tahun. Hal yang ditakutkan adalah ketika anak sudah mengalami kenaikan tekanan darah sejak kecil, maka kemungkinan akan berlangsung sampai dewasa. Tekanan darah tinggi merupakan salah satu faktor yang berpengaruh terhadap penyakit jantung, oleh karena itu orangtua disarankan untuk lebih memperhatikan pola konsumsi anak agar mendapatkan asupan gizi yang baik dan adekuat.

Risiko berbagai macam penyakit dan gangguan gizi yang mempengaruhi tumbuh kembang anak patut mendapatkan perhatian karena asupan gizi dan kecukupan gizi yang berasal dari pola makan sehari-hari sangat menentukan perkembangan dan status gizi anak. 
Rumusan masalah dari penelitian ini adalah bagaimana pola konsumsi Gula, Garam, dan Lemak (minyak) (GGL) pada anak usia sekolah dasar di Kecamatan Tondano Utara, Kabupaten Minahasa.

Penelitian terkait asupan gula, garam, dan lemak pada siswa sekolah dasar di Kecamatan Tondano Utara, Kabupaten Minahasa belum ditemukan. Penelitian relevan dilakukan di Kota Surabaya dengan membandingkan jumlah asupan gula, garam, dan lemak pada anak sekolah dasar di sekolah negeri dan swasta. ${ }^{8}$ Kajian mengenai konsumsi garam, gula, dan lemak umumnya masih terbatas pada analisa jumlah asupan ketiga zat tersebut.

Penelitian ini merupakan penelitian awal yang bertujuan untuk mengetahui gambaran konsumsi garam, gula, dan lemak (minyak) siswa dibeberapa sekolah dasar di Kecamatan Tondano Utara, Kabupaten Minahasa. Penelitian dilakukan dengan menerapkan protokol kesehatan yang berlaku pada masa pandemi Covid19. Melalui penelitian ini diharapkan dapat diperoleh data dasar sebagai informasi awal terkait gambaran asupan garam, gula, dan lemak (minyak), terutama pada masa pandemi Covid-19.

\section{Metode}

Penelitian ini menggunakan metode deskriptif kuantitaif. Pengumpulan data pola konsumsi untuk konsumsi garam, gula, dan lemak (minyak) diperoleh dari kuisioner Semi-Quantitatif Food Frequency (SQFFQ) dan Food Recall 24 hours selama 2x24 jam. Data diri responden diperoleh dari kuisioner dan hasil wawancara, data IMT diperoleh melalui pengukuran berat badan $(\mathrm{kg})$ dan tinggi badan $(\mathrm{cm})$.

Penelitian dilakukan pada bulan Mei 2020 saat pandemi Covid-19 masih berlangsung. Sebanyak 3 dari 6 sekolah yang ada di Kecamatan Tondano Utara, Kabupaten Minahasa bersedia untuk terlibat dalam penelitian ini. Keterbatasan komunikasi dan kesediaan orang tua siswa untuk terlibat sebagai responden di masa pandemi Covid-19 turut mempengaruhi jumlah responden yang terlibat dalam penelitian. Sebanyak 60 siswa dari kelas IIV dari SD GMIM Wulauan 23 siswa, SD GMIM Tonsea Lama 22 siswa, dan SD InPres Marawas 15 siswa di Kecamatan Tondano Utara, Kabupaten Minahasa bersedia menjadi responden penelitian. Selama pengambilan data secara langsung ke setiap rumah responden harus dengan pendampingan dan pengawasan guru dari masing-masing sekolah dan tetap menerapkan protokol kesehatan yang berlaku di wilayah tersebut.

Data pola konsumsi dan konsumsi Gula, Garam, dan Lemak (minyak) (GGL) dari makanan diolah dengan program NutriSurvey untuk mengetahui besar asupan Gula, Garam, dan Lemak (minyak) (GGL) dalam skala data rasio (Gram). Acuan takaran konsumsi gula, garam, dan lemak adalah PERMENKES No. 30 Tahun 2013, yakni konsumsi gula lebih dari 50 gram (4 sendok makan), natrium lebih dari $2.000 \mathrm{mg}$ (1 sendok teh) dan lemak/minyak total lebih dari 67 gram (5 sendok makan).

Data yang diperoleh selanjutnya diolah secara deskriptif dalam bentuk tabel meliputi hasil karakteristik responden, data kebiasaan makan, serta data asupan makan untuk konsumsi gula, garam, dan lemak (minyak). Responden melalui perwakilan guru dari masing-masing sekolah mengisi informed consent sebagai bentuk kesediaan diri menjadi responden penelitian. Penelitian ini telah mendapatkan persetujuan etik dari komisi etik penelitian Fakultas Kedokteran dan Ilmu Kesehatan, Universitas Kristen Satya Wacana Salatiga dengan No. 260/PE/KEPK.UKSW/2020.

\section{Hasil}

Tabel 1 berisi karakteristik umum responden dengan obesitas meliputi kategori usia responden. Responden dari SD GMIM Wulauan merupakan responden terbanyak (23 siswa), sedangkan berdasarkan kategori usia, responden terbanyak adalah siswa usia 7 tahun dari gabungan ketiga sekolah yakni 18 siswa. 
Tabel 1. Karakteristik Usia Responden penelitian

\begin{tabular}{ccccccc}
\hline \multirow{2}{*}{$\begin{array}{c}\text { Usia } \\
\text { (Tahun) }\end{array}$} & $\begin{array}{c}\text { SD GMIM } \\
\text { Wulauan }\end{array}$ & \multicolumn{2}{c}{$\begin{array}{c}\text { SD } \\
\text { GMIM } \\
\text { Tonsea }\end{array}$} & \multicolumn{2}{c}{$\begin{array}{c}\text { SD Inpres } \\
\text { Marawas }\end{array}$} \\
\cline { 2 - 7 } & $\mathbf{n}$ & $\mathbf{\%}$ & $\mathbf{n}$ & $\mathbf{\%}$ & $\mathbf{n}$ & $\mathbf{\%}$ \\
\hline 6 & 5 & 21,7 & 4 & 18,1 & 3 & 20 \\
7 & 9 & 39,1 & 6 & 27,2 & 3 & 20 \\
8 & 5 & 21,7 & 7 & 31,8 & 4 & 26,6 \\
9 & 4 & 17,3 & 5 & 22,7 & 5 & 33,3 \\
\hline
\end{tabular}

Tabel 2. Data kebiasaan makan responden berdasarkan Semi-Quantitatif Food Frequency (SQFFQ)

\begin{tabular}{clcc}
\hline No. & Jenis Makanan & $\begin{array}{c}\text { Frekuensi } \\
\text { (kali)/hari }\end{array}$ & $\begin{array}{c}\text { Berat } \\
\text { (gram)/hari }\end{array}$ \\
\hline 1 & Nasi putih & 3 & 300 \\
2 & Nasi goreng & 1 & 100 \\
3 & Mi instan & 1 & 17.14 \\
4 & Kentang & 1 & 28.57 \\
5 & Ubi & 1 & 11.43 \\
6 & Babi rica & 3 & 25.71 \\
7 & Ikan laut goreng & 2 & 42.86 \\
8 & Ayam goreng & 1 & 34.29 \\
9 & Sosis ayam & 1 & 14.29 \\
\hline
\end{tabular}

Tabel 3. Data Konsumsi Gula, Garam, dan Lemak (minyak) rata-rata hasil Food Recall $2 \times 24$ jam

\begin{tabular}{lcc}
\hline Jenis Asupan & $\begin{array}{c}\text { Rerata Asupan } \\
\text { (gram) }\end{array}$ & Kategori \\
\hline Gula & 0,02 & Kurang \\
Garam & 0,432 & Kurang \\
$\begin{array}{l}\text { Lemak } \\
\text { (minyak) }\end{array}$ & 32,13 & Kurang \\
\hline
\end{tabular}

Data terkait jenis makan yang kerap dikonsumsi oleh para responden dari kelompok pangan karbohidrat, protein, dan lemak berdasarkan lembar isian SemiQuantitatif Food Frequency (SQFFQ) tercantum di dalam Tabel 2. Jenis makanan yang sering dikonsumsi dengan frekuensi 2-3 kali per hari adalah ikan laut goreng, babi rica, dan nasi putih. Jenis makanan lainnya secara rutin dikonsumsi setidaknya 1 kali per hari seperti mi instan, ayam goreng, dan sosis goreng. Konsumsi terbanyak oleh para responden adalah nasi putih dengan berat sekitar 300 gram per hari.

Pada Tabel 3 tercantum asupan gula, garam, dan lemak yang berasal dari minyak berdasarkan data dari Food Recall $2 \times 24$ jam. Ketiga jenis asupan tersebut termasuk ke dalam kategori kurang, masing-masing sebesar 0,02 gram gula, 0,432 gram garam, dan 32,13 gram lemak.

\section{Pembahasan}

SD GMIM Wulauan, SD GMIM Tonsea, dan SD Inpres Marawas adalah sekolah yang terletak di bagian ujung Kecamatan Tondano Utara. Letak masingmasing sekolah dianggap cukup strategis karena masing-masing sekolah dikelilingi oleh rumah warga sehingga memudahkan sebagian anak untuk berangkat ke sekolah, namun tetap ada sebagian anak yang harus menggunakan kendaraan untuk berangkat ke sekolah. Sebagai informasi pendukung, berdasarkan wawancara yang dilakukan kepada perwakilan guru dari masingmasing sekolah, sebelum masa pandemi Covid-19 terdapat banyak penjual jajanan baik makanan atau minuman meskipun di sekolah terdapat kantin. Pola konsumsi siswa terhadap jajanan berubah semenjak pandemi Covid-19 berlangsung dikarenakan situasi yang mengharuskan untuk tetap di rumah. Secara keseluruhan, responden dalam penelitian ini berjumlah 60 orang dengan kisaran usia 6-9 tahun yang kerap jajan di kantin sekolah maupun di luar sekolah sebelum masa pandemi Covid-19.

Secara umum, konsumsi GGL sehari yang berasal dari makanan yang dikonsumsi oleh para responden, apabila dibandingkan dengan Permenkes RI No.30 Tahun 2013 termasuk kategori kurang. ${ }^{5}$ Ketidakcukupan asupan zat gizi pada anak usia sekolah dapat mengakibatkan berbagai dampak negatif pada tubuh karena asupan gizi sangat berperan penting dalam proses pertumbuhan dan perkembangan anak. Kekurangan asupan energi dapat mempengaruhi metabolisme di dalam tubuh. Cadangan energi dalam tubuh yang tersimpan dalam otot dan lemak akan terurai menutupi kekurangan asupan energi. Apabila hal tersebut terus terjadi 
secara berkelanjutan, maka energi yang tersimpan akan habis dan tubuh dapat kehilangan jaringan yang bisa mengakibatkan penurunan berat badan bahkan menghambat pertumbuhan anak. ${ }^{9}$ Kekurangan protein juga dapat menurunkan imunitas anak, sehingga lebih mudah terserang penyakit. ${ }^{10}$

Asupan zat gizi anak yang tidak adekuat sangat berisiko mengalami kelelahan, penurunan konsentrasi belajar, daya tangkap berkurang, dan tidak mampu untuk berpikir dengan baik. Risiko jangka panjang dapat berakibat pada tumbuh kembang yang tidak optimal, sehingga tubuh cenderung pendek dan dapat mengakibatkan risiko stunting. ${ }^{11}$

Berdasarkan wawancara dan data Food Recall 24 jam selama 2 hari yang dilakukan kepada responden, gula yang dikonsumsi adalah gula pasir yang ditambahkan pada teh manis dan kopi. Rata-rata konsumsi gula yang terhitung adalah 0,02 gram karena responden pada penelitian ini jarang mengonsumsi gula. Konsumsi gula pada penelitian ini berasal dari gula yang ditambahkan pada makanan atau minuman seperti susu bubuk coklat, susu kental manis, biskuit, dan permen. Apabila dibandingkan dengan dengan PERMENKES RI No. 30 Tahun 2013 yang menyatakan bahwa konsumsi gula yang dianjurkan adalah 50 gram atau setara dengan 4 sendok makan, maka konsumsi gula pada responden termasuk kategori kurang. ${ }^{5}$ Hasil penelitian di beberapa negara tentang asupan gula pada anak-anak dari jajanan antara lain anak laki-laki usia 6-12 tahun di Amerika mengonsumsi 124 gram/hari, 84 gram/hari di Inggris, Belanda 135 gram/hari, 43 gram/hari di Afrika Selatan, dan 60 gram/hari di Filipina. Salah satu negara di kawasan Asia, yakni Jepang rata-rata asupan gulanya mencapai 24.7 gram. $^{12}$ Penelitian yang dilakukan di Surabaya pada anak SD Negeri dan Swasta menunjukkan hasil bahwa kontribusi asupan GGL dari jajanan masing-masing sebesar $130,6 \%, 86 \%$ dan $65,7 \%$ dari batas konsumsi GGL sehari, sedangkan asupan
GGL dari jajanan di SD swasta berkontribusi berturut-turut sebesar $81,2 \%$, $44 \%$ dan $35,8 \%$ dari batas konsumsi GGL sehari. ${ }^{8}$

Terkait konsumsi garam, asupan garam yang dikonsumsi berasal dari penambah cita rasa garam pada makanan dan juga secara alami berasal dari makanan yang dikonsumsi. Rata-rata konsumsi asupan garam adalah $432.02 \mathrm{mg}$. Berdasarkan PERMENKES RI No. 30 Tahun 2013, konsumsi natrium lebih dari $2.000 \mathrm{mg}$ atau setara dengan 1 sendok teh meningkatkan risiko penyakit hipertensi, stroke, diabetes, dan serangan jantung. ${ }^{5}$ Sebagian besar konsumsi garam di lokasi penelitian termasuk kategori kurang yaitu 0.4 gram. Berdasarkan data SemiQuantitatif Food Frequency (SQFFQ), asupan garam paling banyak berasal dari mi instan, nasi goreng, sosis, tempura, makanan ringan sejenis chiki dan pentol cilot. Konsumsi natrium sekali makan yaitu $17.4 \mathrm{gr} / 1 \mathrm{x}$ makan. Konsumsi natrium berlebih disebabkan karena anak menyukai makanan praktis yang mengandung tinggi garam. Hasil penelitian ini sejalan dengan hasil penelitian Wijayanti (2010) di SDN 06 Petompon Semarang bahwa rata-rata asupan natrium siswa dari jajanan sebesar $3575,5 \mathrm{mg} /$ hari. $^{13}$

Asupan garam berlebih berasal dari natrium dan Monosodium Glutamat (MSG) yang ditambahkan saat memasak makanan terutama berasal dari pedagang yang berjualan di luar sekolah. MSG merupakan Bahan Tambahan Pangan (BTP) yang diizinkan penggunaannya oleh Pemerintah sebagai penyedap rasa dan aroma berdasarkan Permenkes RI No. 722/Menkes/Per/IX/88. ${ }^{14}$ Takaran maksimal penggunaan MSG yang ditetapkan badan pangan dunia sebesar 120 $\mathrm{mg} / \mathrm{kgBB} /$ hari. Apabila konsumsi MSG melebihi acuan $120 \mathrm{mg} / \mathrm{kgBB} / \mathrm{hari}$ berpotensi menimbulkan gangguan lambung, gangguan tidur, dan mual-mual. Konsumsi makanan tinggi natrium dapat peningkatan tekanan darah karena natrium dapat meretensi air sehingga jantung harus 
bekerja lebih keras untuk memompa darah ke seluruh tubuh.

Rata-rata asupan lemak seluruh responden adalah 32.23 gram. Berdasarkan acuan dari Permenkes RI No. 30 Tahun 2013 bahwa konsumsi lemak/minyak total yang dianjurkan tidak lebih dari 67 gram atau setara dengan 5 sendok makan, maka jumlah tersebut termasuk ke dalam kategori kurang, Lemak/minyak yang berlebihan berisiko terhadap penyakit hipertensi, stroke, diabetes dan serangan jantung. Untuk makanan pabrikan kandungan lemak dapat dilihat pada tabel kemasan makanan tersebut, sedangkan untuk makanan olahan di rumah tangga, kandungan lemak dapat secara alami terkandung dalam bahan makanan itu sendiri atau penambahan minyak saat pengolahan. Data konversi penyerapan minyak diperlukan untuk memprediksi jumlah minyak yang terserap dalam makanan akibat proses pengolahan (goreng/tumis) dalam makanan yang dikonsumsi. Presentasi serapan minyak yang tercantum di dalam daftar adalah jumlah serapan per 100 gram makanan matang. Penghitungan serapan minyak goreng dilakukan pada setiap masakan yang digoreng atau ditumis dengan menggunakan minyak goreng, margarine, atau mentega. ${ }^{5}$ Asupan lemak yang kurang akan mengakibatkan tubuh kekurangan energi dan apabila hal tersebut terus menerus terjadi maka akan berdampak pada pertumbuhan anak dan berpotensi mengalami penurunan berat badan. Kekurangan asupan karbohidrat dan lemak juga dapat berdampak pada asupan energi yang dapat menyebabkan terganggunya tumbuh kembang anak. Gejala yang ditunjukkan berupa tubuh terasa lesu, lemah, dan tidak bertenaga. ${ }^{9}$

Makanan yang dikonsumsi responden mengandung lemak/minyak antara lain biskuit, kerupuk, makanan ringan sejenis chiki, tahu goreng, tempe goreng, ayam goreng, babi goreng, susu, ubi goreng, dan telur ayam goreng. Sebagian besar makanan berasal dari makanan yang digoreng. Makanan yang digoreng memiliki cita rasa lebih nikmat dan gurih apabila dibandingkan dengan makanan yang tidak digoreng karena terjadi pemanasan protein, karbohidrat, lemak, dan komponen minor lainnya. Terlebih, makanan yang berukuran tipis memiliki daya serap minyak lebih banyak dibandingkan dengan yang tebal. Berdasarkan hasil penelitian Saadah pada penjual penyetan di kawasan Tembalang di Semarang menunjukkan bahwa sebanyak $65,7 \%$ pedagang tidak mengganti minyak goreng dari awal membuka warung hingga tutup, bahkan sebanyak $68,8 \%$ pedagang justru menambahkan minyak goreng bekas dengan minyak goreng baru selama penjualan. ${ }^{15}$ Minyak kelapa sawit yang digunakan secara berulang-ulang dapat merusak vitamin dan asam lemak yang terdapat pada minyak. Hal ini disebabkan oleh proses oksidasi dan polimerasi. Dampak yang timbul jika konsumsi minyak yang dipanaskan secara berulangulang yaitu gejala keracunan seperti iritasi saluran pencernaan, diare dan kanker.

Cara mencegah anak jajan sembarangan adalah perlu adanya dukungan dari pihak sekolah, orangtua, akademisi, penyedia layanan kesehatan serta kesadaran dari siswa. Orangtua dapat menyediakan bekal makanan dan minuman bersih dan sehat yang disiapkan dari rumah agar tidak membiasakan anak jajan sembarangan. Apabila berkumpul bersama anggota keluarga, orangtua diharapkan tidak membiasakan anak untuk mengkonsumsi makanan cepat saji dengan alasan praktis, mudah, dan cepat. ${ }^{16}$

Pihak sekolah dapat menyediakan kantin sehat di dalam area sekolah dan memberikan arahan untuk tidak jajan sembarangan di luar lingkungan sekolah. Pendidikan terkait gizi bagi anak dapat dilakukan secara sinergis antara pihak penyedia layanan Kesehatan seperti Puskesmas dengan pihak akademisi dan sekolah. Bentuk kegiatan yang dapat dilakukan misalnya memberikan edukasi terkait konsumsi makanan bersih dan 
sehat.

Para siswa dan orangtua juga harus menyadari pentingnya untuk memilih dan memilah makanan yang bersih, sehat, dan bergizi sehingga dapat mencegah terjadinya gangguan kesehatan pada waktu yang akan datang. Ancaman penyakit yang berpeluang muncul akibat konsumsi gula, garam, dan lemak berlebih diantaranya obesitas, dislipidemia, hipertensi, dan gangguan toleransi glukosa. ${ }^{17}$

Hasil penelitian di Surabaya menyebutkan bahwa pemberian uang saku yang relatif besar bagi anak usia SD sekitar Rp 5.000,- memberikan peluang bagi siswa untuk membeli jajanan. ${ }^{8}$ Perlu ada kebijakan dan arahan dari orangtua bagi anak untuk memberikan dan memanfaatkan uang jajan tersebut agar tidak digunakan hanya untuk jajan secara sembarangan.

\section{Kesimpulan}

Asupan GGL pada siswa di SD GMIM Wulauan, SD GMIM Tonsea, dan SD Inpres Marawas pada masa pandemi Covid-19 termasuk kategori kurang. Meskipun demikian, asupan GGL tetap perlu dijaga agar tidak melebihi batas konsumsinya. Cara untuk membatasi konsumsi jajanan yang mengandung GGL yaitu dengan membatasi jajanan terutama jajanan manis, gurih dan berlemak. Selain itu, diharapkan adanya pendidikan gizi bagi anak terkait makanan dan jajanan sehat yang dilakukan oleh pihak sekolah, akademisi, maupun penyedia layanan kesehatan setempat seperti Puskesmas.

Penelitian selanjutnya dapat lebih memaksimalkan jumlah sekolah dan siswa sebagai responden penelitian. Pandemi Covid-19 diduga turut mempengaruhi asupan GGL siswa, sehingga dengan jumlah responden yang lebih banyak dan melakukan perbandingan asupan GGL siswa pada masa sebelum pandemi dan semasa pandemi Covid-19 akan dapat memperoleh gambaran asupan GGL secara komprehensif di Kecamatan Tondano Utara, Kabupaten Minahasa.

\section{Daftar Pustaka}

1. Irianto K. Gizi Seimbang dalam Kesehatan Reproduksi. Bandung: Alfabeta; 2014.

2. Almatsier S, Soetardjo S, Soekarti M. Gizi Seimbang dalam Daur Ulang Kehidupan. Jakarta: PT Gramedia Pustaka Utama; 2011.

3. Istiany A, Rusilanti. Gizi Terapan. Bandung: PT Remaja Rosdakarya; 2013.

4. Departemen Kesehatan Republik Indonesia. Informasi Pangan dan Gizi Edisi II. Jakarta: Departemen Kesehatan Republik Indonesia; 2011.

5. Peraturan Menteri Kesehatan Republik Indonesia (PERMENKES RI) Nomor 30 Tahun 2013. Pencantuman Informasi Kandungan Gula, Garam, dan Lemak serta Pesan Kesehatan untuk Pangan Olahan dan Pangan Siap Saji. Direktorat Jenderal Bina Gizi dan Kesehatan Ibu dan Anak, Direktorat Bina Gizi, Kementrian Republik Indonesia; 2013.

6. Direktorat Standarisasi Produk Pangan, Deputi Bidang Pengawasan Kemanan Pangan dan Bahan Berbahaya, Badan Pengawas Obat dan Makanan Republik Indonesia. Pedoman Pangan Jajanan Anak Sekolah untuk Pencapaian Gizi Seimbang bagi Orangtua, Guru dan Pengelola Kantin. Jakarta: Direktorat SPP, Deputi III, Badan POM RI; 2012.

7. Tim Penulis Poltekkes Depkes Jakarta I. Kesehatan Remaja Problem dan Solusinya. Jakarta: Salemba Medika; 2012.

8. Nawang FRMP, Adriyanto. Analisis Asupan Gula, Garam, dan Lemak (GGL) dari Jajanan pada Anak Sekolah Dasar Negeri dan Swasta di Kota Surabaya. Amerta Nutrition. 2019 Mar; 3 (1): 58-62.

9. Utari LD, Ernalia Y, Suyanto. Gambaran Status Gizi dan Asupan Zat Gizi pada Siswa Sekolah Dasar Kecamatan Sungai Sembilan, Kota Dumai. Jurnal Online Mahasiswa Fakultas Kedokteran, Universitas Riau. 2016 Feb; 3 (1): $1-17$.

10. Achmadi, UF. Kesehatan Masyarakat Teori dan Aplikasi. Jakarta: RajaGrafindo; 2013.

11. Siregar YHW, Ernalia Y, Restuastuti T. Gambaran Status Gizi pada Siswa Sekolah Dasar di Desa Teluk Kiambang, Kecamatan Tempuling, Kabupaten Indragiri Hilir. Jurnal Online Mahasiswa Fakultas Kedokteran, Universitas Riau. Okt 2016; 3 (2): 1-13.

12. Takeichi H, Taniguchi H, Fukinbara M, Tanaka N, Shikanai S, Sarukura N, et al. Sugar Intakes from Snacks and Beverages in Japanese Children. Journal of Nutritional Science and Vitaminology. 2012 Jan; 58 (2): 113-117.

13. Wijayanti, E. Asupan Natrium dari Makanan Jajanan dan Tekanan Darah Siswa Sekolah Dasar. (2010)

14. Peraturan Menteri Kesehatan Republik Indonesia (PERMENKES RI) Nomor 
722/MENKES/PER/IX/1988. Bahan Tambahan Makanan. Menteri Kesehatan Republik Indonesia; 1988.

15. Saadah A, Martini M, Yuliawati S. Gambaran Minyak Goreng yang Dipakai Penjual Penyetan di Tembalang Semarang. Jurnal Kesehatan Masyarakat. 2016 Okt; 4 (4): 311-318.
16. Icha P. Perilaku Konsumsi Makanan Cepat Saji pada Remaja dan Dampaknya bagi Kesehatan. 2018 Sep; 14 (2): 144-153.

17. Jagadish CD. Fast Food Consumption in Children: A Review. Medical \& Clinical
Reviews.
2015;
1
(1):1-4. 